\title{
Indirect interaction in milk between proteolytic and isogenic non-proteolytic strains of Lactococcus lactis. II. Effect of pre-culturing by a proteolytic strain
}

\author{
V Juillard *, J Richard \\ INRA, Station de Recherches Laitières, 78352 Jouy-en-Josas cedex, France
}

(Received 14 September 1990; accepted 29 November 1990)

\begin{abstract}
Summary - Indirect interaction between isogenic strains of Lactococcus lactis growing in milk was examined by pre-culturing milk with a proteolytic strain. The bacterium used for the second culture was either the same proteolytic strain, or one of its non-proteolytic variants. When grown in precultured milk, the proteolytic strain exhibited the same general behaviour as when cultured in control milk, ie exponential growth was biphasic, growth rates during both exponential phases were not significantly affected, and maximum populations were similar. However, the time of shift from the first to the second exponential growth phase occurred earlier in pre-cultured than in control milk. When grown in pre-cultured milk, the non-proteolytic variant exhibited a slower growth rate and a lower maximum population than when grown in control milk. Moreover, abundant growth of the proteolytic strain during pre-culturing caused complete inhibition of the non-proteolytic strain as the second culture. Inhibition of the non-proteolytic variant that resulted from pre-culturing milk with the proteolytic strain was suppressed by adding a non-proteic nitrogen source to milk, indicating that the proteolytic strain grew in milk without accumulating non-proteic nitrogen sources assimilable by the variant. Similar inhibition was also observed using 12 other pairs of isogenic proteolytic / non-proteolytic strains of $L$ lactis.
\end{abstract}

Lactococcus lactis / proteolytic strain / pre-cultured milk / non-proteic nitrogen fraction / growth-limiting substrate

Résumé - Interaction indirecte entre souches isogéniques de Lactococcus lactis dans le lait. II. Effet de la préculture par une souche protéolytique. L'étude de l'interaction indirecte entre souches isogéniques de Lactococcus lactis a été poursuivie en précultivant le lait par une souche protéolytique. La souche ensemencée en second était soit la même que celle utilisée pour la préculture du lait, soit un variant isogénique non protéolytique.

La souche protéolytique incubée dans un lait précultivé par elle-même avait le même comportement général que dans le lait témoin (sans préculture) : sa croissance exponentielle était biphasique; le taux de croissance de chacune des 2 phases exponentielles n'était pas affecté par la pré-culture du lait, et la densité cellulaire maximale était la même. Cependant, le niveau cellulaire auquel le changement de taux de croissance était observé était plus faible que dans le lait témoin. Le variant non protéolytique, incubé dans le lait précultivé par la souche protéolytique, atteignait un niveau maximal de population plus faible que dans le lait témoin, et ce, avec un taux de croissance plus lent. Lors-

* Correspondence and reprints 
que la préculture était stoppée durant sa seconde phase de croissance exponentielle, le variant non protéolytique était incapable de se développer dans le lait précultivé. L'effet inhibiteur de la préculture du lait par une souche protéolytique sur son variant non-protéolytique était supprimé en ajoutant au lait une source d'azote non protéique, ce qui montre clairement que la souche protéolytique se développait dans le lait sans y accumuler de substrats azotés utilisables pour la croissance d'une souche isogénique. La conséquence de cette croissance sans accumulation était une compétition indirecte entre les 2 souches pour les sources d'azote non protéique, constatée avec 12 autres paires de souches de L lactis.

Lactococcus lactis / souche protéolytique / préculture du lait / fraction azotée non protéique / croissance en condition de substrat limitant

\section{INTRODUCTION}

Pre-culturing milk with a proteolytic (prt+) strain of Lactococcus lactis reportedly decreased the population level attained by a subsequent culture of an isogenic nonproteolytic (prt) variant incubated for $6 \mathrm{~h}$ in the same milk (Juillard and Richard, 1989). Two hypotheses were proposed to explain this observation: a), production of one (or more) inhibitory substance(s) by the first culture; and b), depletion of particular milk nutriments during pre-culture. In support of the latter, when non-proteic nitrogen (NPN) was eliminated from milk by pre-culturing with a prt variant of $L$ lactis, subsequent growth of the parental $\mathrm{prt}^{+}$ strain was partly inhibited, despite its proteolytic activity (Juillard and Richard, 1990).

These observations suggest that proteolytic activity of lactococci is too low to produce sufficient NPN for optimal growth in milk (Hugenholtz et al, 1987). This is in contradiction with results from several studies (Bande et al, 1970; Ibragimova et al, 1973; Lawrence et al, 1976; Kamaly and Marth, 1989), which showed that the total NPN-content of milk increases during growth of proteolytic lactococci.

In an attempt to confirm such inhibition and elucidate the corresponding reasons, the consequence of pre-culturing milk with a $\mathrm{prt}^{+}$strain of $L$ lactis was further studied.
The strain used in the second culture was either the same $\mathrm{prt}^{+}$strain, or an isogenic prt variant. Because of impeding technological implications, the inhibitory effect of pre-culturing on bacterial growth (population densities and growth rates) was also quantified.

\section{MATERIALS AND METHODS}

\section{Strains}

The study was performed using one pair of reference strains belonging to the species Lactococcus lactis subsp lactis: the prt+ strain CNRZ 1076 , and an isogenic non-proteolytic variant, CNRZ 1075. Results obtained with this pair of strains were further confirmed using 12 other $\mathrm{prt}^{+} / \mathrm{prt}$ pairs of $L$ lactis, with 4 pairs each belonging to subspecies lactis (CNRZ 141, 145, 261 and 377), subsp lactis biovar diacetylactis (CNRZ 125, 187, 257 and 267), and subsp cremoris (CNRZ 112, 114, 379 and 380 ). Culture propagation and strain handling were carried out as previously described (Hassan et al, 1989; Juillard and Richard, 1989).

\section{Culture medium}

The culture medium was reconstituted $(10 \%$ w/ v) non-fat dry milk (low-heat powder Nilac, $\mathrm{NIZO}$ ) in sterile water. Milk was pre-cultured with the $\mathrm{prt}^{+}$strain for specific periods of time to obtain fixed cell populations as determined by $\mathrm{pH}$ 
measurements or bioluminescence (Juillard and Richard, 1990). The $\mathrm{pH}$ of pre-cultured milk was then adjusted to that of the control milk $(\mathrm{pH} c a$ 6.80 ), before pasteurization for $30 \mathrm{~min}$ at $63^{\circ} \mathrm{C}$. The residual flora was consistently low $(<5 x$ $10^{2} \mathrm{cfu} / \mathrm{ml}$ ). Previous work (Juillard and Richard, 1989) demonstrated that behaviour of the second culture was not significantly affected by $\mathrm{pH}$ adjustment, pasteurization, presence of dead cells, or lactate $(5 \mathrm{~g} / \mathrm{l})$, the latter of which corresponds to the amount of lactate produced by the $\mathrm{prt}^{+}$strain when grown to a level of $10^{9} \mathrm{cfu} / \mathrm{ml}$.

When necessary, the NPN content of precultured milk was artificially increased by adding either a source of peptides $(0.1 \%$ proteosepeptone No 3, Difco), or a mixture of the 18 normal amino acids $(0.1 \mathrm{~g} / 1$ of each; glutamine and asparagine omitted).

\section{Culture conditions and bacterial enumeration}

Inoculation and culture conditions were identical to those previously described (Juillard and Richard, 1990). The inoculation level of the cultures was ca $10^{6} \mathrm{cfu} / \mathrm{ml}$ (except where otherwise stated), and the incubation temperature $30^{\circ} \mathrm{C}$.

Cell populations were estimated as previously described (Hassan et al, 1989; Juillard and Richard, 1990) by plating appropriate dilutions on M17 medium (Terzaghi and Sandine, 1975). The homogeneity of the population at beginning and end of incubation was verified using FSDA medium (fast-slow differential agar; Huggins and Sandine, 1984) with the population under study always representing $>97 \%$ of the total population.

Growth rates $(\mu)$ were calculated from Monod's equation $N=N_{0} 2^{\mu t}$ (Monod, 1949), where $\mathrm{N}$ is the population density. Bacterial density $(\log \mathrm{cfu} / \mathrm{ml})$ was first plotted against time, and slopes (s) of the linear phases of growth were estimated by linear regression analysis (Hassan et al, 1989). Values for growth rates were then calculated from the slopes of the growth curve using the following formula:

$$
\mu=\log 10 / \log 2 \times s=3.32 \times s
$$

\section{RESULTS}

\section{Growth of prt* and prt reference strains and $\mathrm{pH}$ change in milk pre- cultured with the prt+ strain}

The reference $\mathrm{prt}^{+}$strain (CNRZ 1076) and its prt variant (CNRZ 1075) were grown in both control and prt+-pre-cultured milk. Figure 1 shows the population dynamics and $\mathrm{pH}$ changes for each strain when milk was pre-cultured to a final population of $\mathrm{ca} 10^{8}$ $\mathrm{cfu} / \mathrm{ml}$.

Pre-culturing milk with the reference $\mathrm{prt}^{+}$ strain inhibited subsequent growth of the isogenic prt variant (fig 1A). Maximum population was $\approx 50 \%$ lower in pre-cultured $\left(7.9 \times 10^{7} \mathrm{cfu} / \mathrm{ml}\right)$ than in control milk (1.6 $\mathrm{x}$ $\left.10^{8} \mathrm{cfu} / \mathrm{ml}\right)$. The duration of the exponential growth phase ( $\approx 4 \mathrm{~h}$ in both milks) was not significantly affected by pre-culturing. However, the growth rate was lower (1.2 $\mathrm{h}^{-1}$ vs $1.7 \mathrm{~h}^{-1}$ in control milk). This lower maximum population and growth rate resulted in slower acidification of precultured milk. After $8 \mathrm{~h}$ of incubation, the $\mathrm{pH}$ difference between pre-cultured and control milk was $\approx 0.1 \mathrm{pH}$ unit, which corresponds to a 2-h delay in milk acidification by the prt culture.

The effect that pre-culturing milk with the $\mathrm{prt}^{+}$strain had on subsequent growth of the same prt+ strain was quite different (fig 1B). The maximum population attained by the $\mathrm{prt}^{+}$strain was not affected $(\approx 1.5 \mathrm{x}$ $\left.10^{9} \mathrm{cfu} / \mathrm{ml}\right)$. As in control milk, the exponential growth phase of the $\mathrm{prt}^{+}$strain remained biphasic in pre-cultured milk, with both exponential growth rates relatively unaffected by pre-culturing (1.8 vs $1.7 \mathrm{~h}^{-1}$ for the first phase, and 1.1 vs $1.2 \mathrm{~h}^{-1}$ for the second phase, respectively). However, the split in growth rate occurred 90 min earlier 

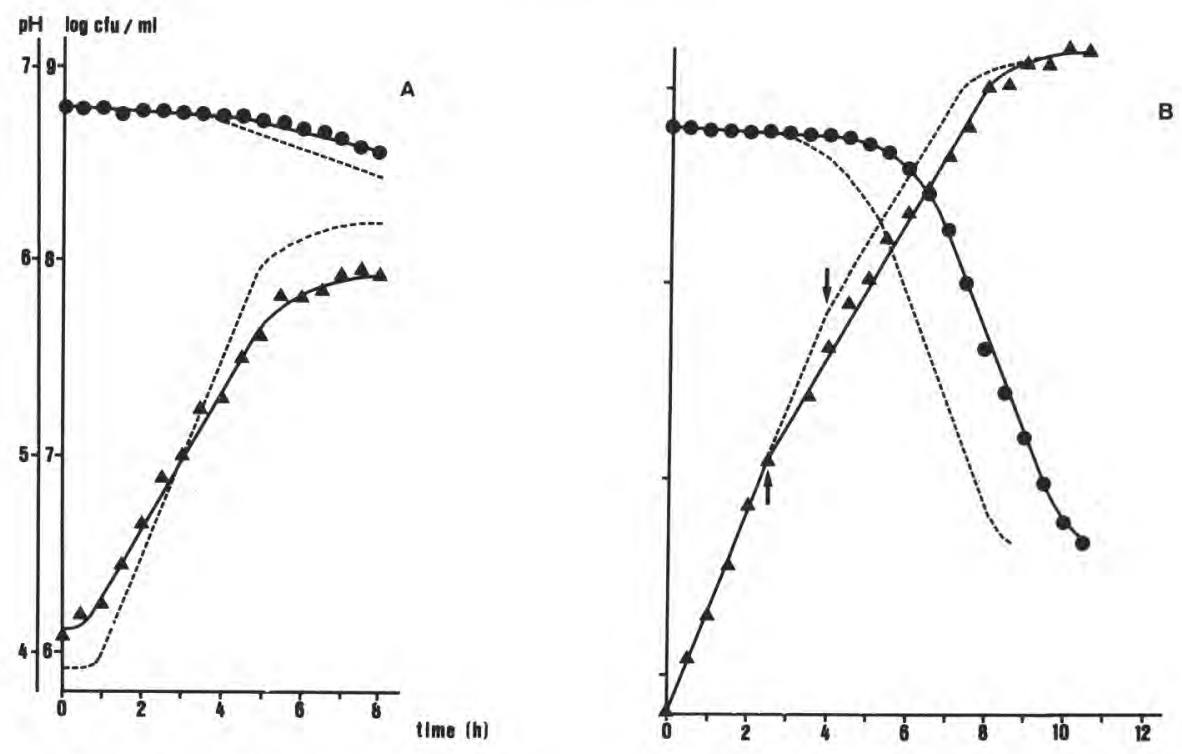

Fig 1. Growth of Lactococcus lactis subsp lactis CNRZ 1075 (prt strain) and CNRZ 1076 (prt+ strain) in milk pre-cultured with the $\mathrm{prt}^{+}$strain. A: prt strain; B: $\mathrm{prt}^{+}$strain; $\bullet: \mathrm{pH} ; \mathbf{\Delta}:$ cell population; $\uparrow$ : change in exponential growth rate; … (densities at): growth and acidification in control milk (population of the $\mathrm{prt}^{+}$strain after pre-culturing was $1.7 \times 10^{8} \mathrm{cfu} / \mathrm{ml}$ in $\mathrm{A}$ and $1.2 \times 10^{8} \mathrm{cfu} / \mathrm{ml} \mathrm{in} \mathrm{B)}$.

Croissance et acidification de Lactococcus lactis subsp lactis CNRZ 1075 (souche prt) et CNRZ 1076 (souche $\mathrm{prt}^{+}$) dans du lait précultivé par la souche prt. A: souche prt-; B: souche prt; : $\mathrm{pH}$; $\Delta$ : densité de population; $\uparrow$ : changement de phase exponentielle de croissance; $\cdots$ : croissance et acidification dans le lait témoin (densité de population en fin de pré-culture : $1,7.10^{8} \mathrm{ufc} / \mathrm{ml}$ en $A$ et $1,2.10^{8} \mathrm{ufc} / \mathrm{ml}$ en $\mathrm{B}$ ).

in pre-cultured than in control milk. Consequently, population densities at which this change occurred were lower in precultured than in control milk $\left(1.2 \times 10^{7} \mathrm{cfu} /\right.$ $\mathrm{ml}$ vs $\left.8 \times 10^{7} \mathrm{cfu} / \mathrm{ml}\right)$. Since the second growth rate was slower than the first, the time needed to attain the same population as in control milk was slightly longer ( $\mathrm{ca}$ $0.5 \mathrm{~h}$ delay).

Since the growth rate of the second exponential growth phase and the maximum population of the $\mathrm{prt}^{+}$strain were not affected by pre-culturing, the acidification rate was similar in both pre-cultured and control milk with a decrease of $\approx 0.5 \mathrm{pH}$ unit per $\mathrm{h}$ between $\mathrm{pH} 6$ and $\mathrm{pH} 5$. However, acidification of pre-cultured milk was delayed as a result of an earlier change in exponential growth phase $(\approx 1.5 \mathrm{~h}$ delay to obtain $\mathrm{pH}$ values $<6$ ).

Effect of pre-culture levels of the reference prtt strain on subsequent growth of the prt variant or the prt+ strain

Milk was pre-cultured with the reference $\mathrm{prt}^{+}$strain for various lengths of time to obtain cell populations ranging from $2.5 \times 10^{7}$ to $1.3 \times 10^{9} \mathrm{ctu} / \mathrm{ml}$. The effect of pre- 
culturing on growth parameters of the prt variant as the second culture is presented in table I.

Stopping sample pre-cultured with the prt $^{+}$strain during the first exponential growth phase (populations < $10^{8} \mathrm{cfu} / \mathrm{ml}$ ) had little effect on the growth parameters for the prt variant, with maximum populations and growth rates similar to that of the control milk.

When pre-culturing ceased at a populatio density of $\mathrm{ca} 10^{8} \mathrm{cfu} / \mathrm{ml}\left(8.8 \times 10^{7}\right.$ and $1.7 \times 10^{8} \mathrm{cfu} / \mathrm{ml}$ in table I) ie, the level at which a shift in exponential growth phase normally occurs, both maximum populations and growth rates were markedly lower than in control milk.

Furthermore, stopping the pre-culture during the second exponential growth phase of the prt $^{+}$strain (cell densities at the end of pre-culturing $>2 \times 10^{8} \mathrm{cfu} / \mathrm{ml}$ ) made it impossible to detect any exponen- tial growth during the second culture, with populations of the second culture increasing only ca 2 -fold after $8 \mathrm{~h}$ of incubation.

Results using the prt+ strain as the second culture are shown in table II. When pre-culturing was stopped mid-way through the first exponential growth rate ( 7 $\times 10^{7} \mathrm{cfu} / \mathrm{ml}$ ), the culture remained biphasic, with both growth rates unaffected. However, the level at which the split in growth rate usually occurs decreased, as previously observed (see previous section). When pre-culturing ceased during the second exponential growth phase $\left(3.6 \times 10^{8}\right.$ $\mathrm{cfu} / \mathrm{ml})$, the first exponential growth phase of the second culture was eliminated. However, the growth rate during the second exponential growth phase remained unaffected. In either case, pre-culturing milk did not affect maximum populations in the second culture.

Table I. Growth of Lactococcus lactis subsp lactis CNRZ 1075 (prt strain) in milk pre-cultured with different levels of the parental prt+ strain (CNRZ 1076).

Croissance de Lactococcus lactis subsp lactis CNRZ 1075 (souche prt) dans du lait précultivé par sa souche parentale prt+ (CNRZ 1076) jusqu'à différents niveaux de population.

\begin{tabular}{lll}
$\begin{array}{l}\text { First culture } \\
\text { (prt+ strain) }\end{array}$ & \multicolumn{2}{c}{$\begin{array}{c}\text { Second culture } \\
\text { (prt strain) }\end{array}$} \\
\cline { 2 - 3 } $\begin{array}{l}\text { Level at the } \\
\text { end of pre-culture } \\
\text { (cfu/ml) }\end{array}$ & $\begin{array}{c}\text { Growth rate } \\
\left(h^{-1}\right)\end{array}$ & $\begin{array}{c}\text { Maximum population } \\
\text { (cfu/ml) }\end{array}$ \\
\hline & & \\
$0 \mathrm{a}$ & $1.7 \pm 0.1$ & $(1.6 \pm 0.04) \times 10^{8}$ \\
$2.5 \times 10^{7}$ & 1.6 & $1.6 \times 10^{8}$ \\
$7.5 \times 10^{7}$ & 1.7 & $1.3 \times 10^{8}$ \\
$8.8 \times 10^{7}$ & 1.4 & $1.1 \times 10^{8}$ \\
$1.7 \times 10^{8}$ & 1.2 & $7.9 \times 10^{7}$ \\
$4.3 \times 10^{8}$ & $*$ & $1.9 \times 10^{7}$ \\
$1.3 \times 10^{9}$ & $*$ & $2.5 \times 10^{7}$ \\
& &
\end{tabular}

Inoculation level of the second culture was ca $10^{7} \mathrm{cfu} / \mathrm{ml}$. a: Control milk (without pre-culture); average of 3 determinations. * : Impossible to determine (no exponential growth).

Niveau d'ensemencement de la seconde culture : $10^{7}$ ufc/ml environ. a : Lait témoin (sans préculture); moyenne de 3 déterminations. " : pas mesurable (absence de croissance exponentielle). 
Table II. Growth of Lactococcus lactis subsp lactis CNRZ 1076 (prt+ strain) in milk pre-cultured with different levels of the same strain.

Croissance de Lactococcus lactis subsp lactis CNRZ 1076 (souche prt+) dans du lait précultivé par la même souche jusqu'à différents niveaux de population.

\begin{tabular}{|c|c|c|c|c|}
\hline \multirow{3}{*}{$\begin{array}{l}\text { First culture } \\
\text { (prt+ strain) } \\
\text { Level at the } \\
\text { end of pre-culture } \\
(\mathrm{cfu} / \mathrm{ml})\end{array}$} & \multicolumn{4}{|c|}{$\begin{array}{l}\text { Second culture } \\
\text { (prt+ strain) }\end{array}$} \\
\hline & \multicolumn{2}{|c|}{$\begin{array}{c}\text { Growth rates } \\
\left(\left(h^{-1}\right)\right.\end{array}$} & \multicolumn{2}{|c|}{$\begin{array}{l}\text { Population densities } \\
\text { (log cfu/ml) }\end{array}$} \\
\hline & 1st phase & 2nd phase & Split & Maximum \\
\hline $0^{a}$ & $1.7 \pm 0.1$ & $1.2 \pm 0.1$ & $7.9 \pm 0.1$ & $9.4 \pm 0.1$ \\
\hline $7 \times 10^{7}$ & 1.8 & 1.2 & 7.7 & 9.3 \\
\hline $3.6 \times 10^{8}$ & nd & 1.2 & nd & 9.4 \\
\hline
\end{tabular}

Inoculation level of the second culture was $\mathrm{ca} 10^{7} \mathrm{cfu} / \mathrm{ml}$. a: Control milk (without pre-culture); average of 3 determinations. nd: Not detectable.

Niveau d'ensemencement de la seconde culture : $10^{7} \mathrm{ufc} / \mathrm{ml}$ environ. ${ }^{a}$ : Lait témoin (sans préculture); moyenne de 3 déterminations. nd: Non détectable.

\section{Addition of proteose-peptone to milk during secondary culturing with the ref- erence prt variant}

Milk was pre-cultured with the reference $\mathrm{prt}^{+}$strain to obtain cell populations of 8.9 $\times 10^{7}$ and $4.9 \times 10^{8} \mathrm{cfu} / \mathrm{ml}$, just before and after the change in growth rate, respectively. The prt strain CNRZ 1075 was then grown in both control and pre-cultured milks. When this culture was nearing stationary phase (as determined by bioluminescence), $0.1 \%$ proteose-peptone was added to the milk. Results of this experiment are shown in figure 2.

Inhibition by pre-culturing milk with prt $^{+}$ strain was again confirmed, with the degree of inhibition increasing with the population level at the end of pre-culturing.

In both cases, growth of the prt strain resumed after pre-cultured milk was supplemented with proteose-peptone. In supplemented milks, new growth rates were not markedly different from those observed in control milk (1.6 $\mathrm{h}^{-1}$ in fig $2 \mathrm{~A}$ and $2 \mathrm{~B}$, vs $1.7 \pm 0.1 \mathrm{~h}^{-1}$ in control milk). However, maximum populations were $\approx 9-10$-fold higher in supplemented than in control milk $\left(1.9 \times 10^{9} \mathrm{cfu} / \mathrm{ml}\right.$ in fig $2 \mathrm{~A}$ and $7.0 \times 10^{8}$ $\mathrm{cfu} / \mathrm{ml}$ in fig $2 \mathrm{~B}$, vs $1.6 \times 10^{8} \mathrm{cfu} / \mathrm{ml}$ in control milk). These maximum populations are similar to values observed in control milk supplemented with proteose-peptone ( $2 \mathrm{x}$ $\left.10^{9} \mathrm{cfu} / \mathrm{ml}\right)$.

Since proteose-peptone is a peptic hydrolysate of animal tissues, this substance could contain other growth factors besides NPN sources, including traces of sugar, nucleic acids or metals. To acertain that regrowth of the prt strain was only due to NPN supplementation, similar experiments were repeated using a mixture of amino acids instead of proteose-peptone. After $12 \mathrm{~h}$ of incubation, the population density of the second culture was $\approx 5 \times 10^{8} \mathrm{cfu} / \mathrm{ml}$ in the supplemented pre-cultured milk, clearly indicating that regrowth in milk was 

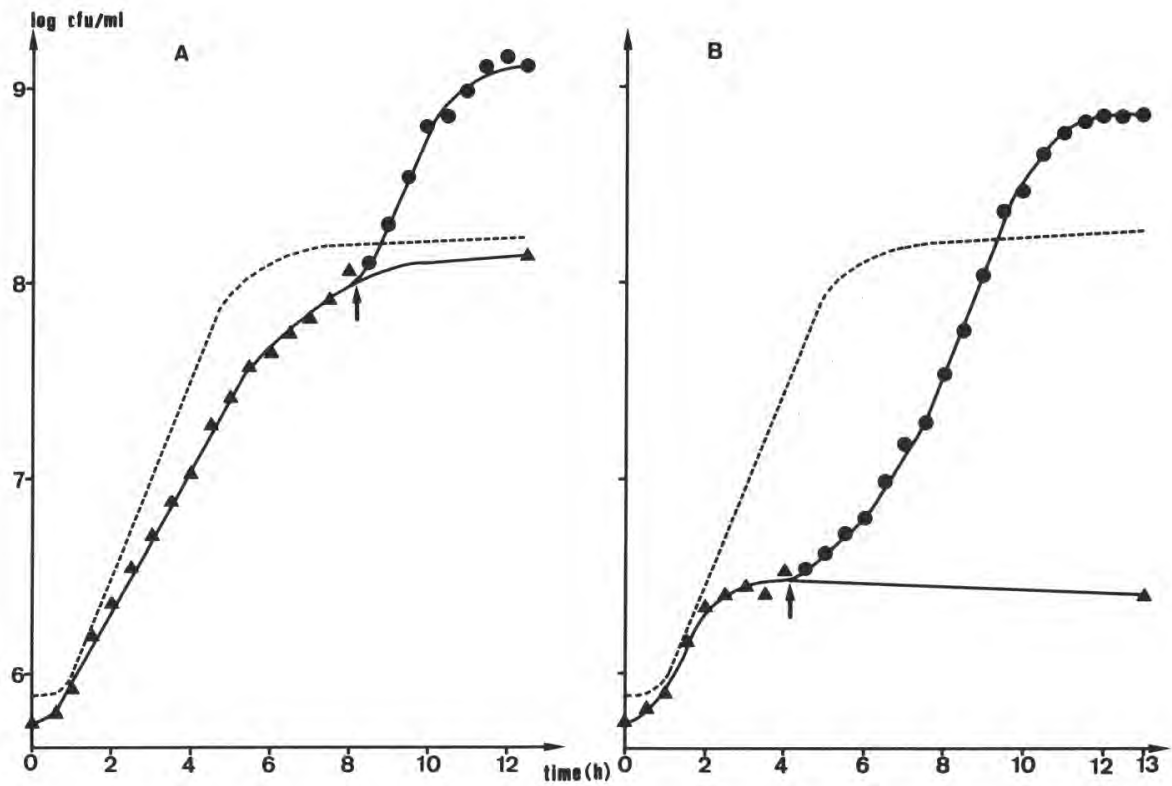

Fig 2. Effect of adding proteose-peptone on growth of Lactococcus lactis subsp lactis CNRZ 1075 (prt strain) in milk pre-cultured with the parental prt ${ }^{+}$strain CNRZ 1076. Milk was pre-cultured with the $\mathrm{prt}^{+}$strain up to (A) $8.9 \times 10^{7} \mathrm{cfu} / \mathrm{ml}$ (end of the first exponential growth phase) and (B) $4.9 \times 10^{8}$ $\mathrm{cfu} / \mathrm{ml}$ (middle of the second exponential growth phase). Growth of the prt variant in pre-cultured milk before $(\mathbf{\Lambda})$ and after $(\boldsymbol{)})$ supplementation with $1 \mathrm{~g} / \mathrm{l}$ of proteose-peptone $(\uparrow)$, and in reference milk (...). $\uparrow:$ time of supplementation.

Effet de l'addition de protéose-peptone sur la croissance de Lactococcus lactis subsp lactis CNRZ 1075 (souche prt) dans du lait précultivé par sa souche parentale prt' CNRZ 1076. Densité bactérienne de la souche prt' en fin de préculture : $8,9.10^{7} \mathrm{ufc} / \mathrm{ml}$ en $A$ (fin de sa première phase exponentielle de croissance) et $4,9.10^{8} \mathrm{ufc} / \mathrm{ml}$ en $B$ (milieu de sa seconde phase exponentielle de croissance). Croissance du variant prt dans le lait précultivé, avant (A) et après (0) supplémentation avec $1 \mathrm{~g} / \mathrm{l}$ de protéose-peptone ( $\uparrow)$, et dans le lait témoin (...). $\uparrow$ : instant de la supplémentation

a direct consequence of NPN supplementation.

\section{Extension of this study to other prt+ / prt L lactis pairs}

A somewhat simplified experimental design was used to examine 12 additional $\mathrm{prt}^{+} / \mathrm{prt} L$ lactis pairs. Pre-culturing was terminated when the $\mathrm{pH}$ of the milk de- creased to ca 5.3 (near the end of the second exponential growth phase of the $\mathrm{prt}^{+}$ strains giving cell densities of ca $10^{9} \mathrm{cfu} /$ $\mathrm{ml})$. Each prt strain was grown in control milk and milk pre-cultured with its parental $\mathrm{prt}^{+}$strain. The prt strains (as second cultures) were inoculated at $10^{7} \mathrm{cfu} / \mathrm{ml}$.

Cell densities of the prt strains and $\mathrm{pH}$ in both pre-cultured and control milk were determined after $4 \mathrm{~h}$ of incubation at $30^{\circ} \mathrm{C}$. (It was expected that both cultures would 
be in stationary phase, leading to maximum differences in $\mathrm{pH}$ and cell populations). The effect of pre-culturing on the second culture is expressed as the difference in $\mathrm{pH}$ between pre-cultured and control milk and the ratio of cell densities following incubation, so that an inhibitory effect gives a positive $\mathrm{pH}$ difference and a population ratio $<1.0$, and vice versa (Juillard and Richard, 1990).
In control milk, prt strains attained populations of $1.9( \pm 0.5) \times 10^{8} \mathrm{cfu} / \mathrm{ml}$ following $4 \mathrm{~h}$ of incubation with a corresponding $\mathrm{pH}$ value of $6.55( \pm 0.05)$. In contrast, all prt strains were inhibited in pre-cultured milk (table III), with population ratios generally $<1.0$. Furthermore, some strains were markedly inhibited (CNRZ 145, 187 and 379); whereas others were inhibited to a lesser degree (CNRZ 261, 267 and 112).

Table III. Effect of proteose-peptone $(1 \mathrm{~g} / \mathrm{l})$ on growth of different prt strains of Lactococcus lactis in milk pre-cultured with the corresponding prt+ parental strain.

Effet de la protéose-peptone $(1 \mathrm{~g} / \mathrm{l})$ sur la croissance de différentes souches prt de Lactococcus lactis dans du lait précultivé par la souche prt+ correspondante.

\begin{tabular}{|c|c|c|c|c|}
\hline \multirow[t]{2}{*}{ Strains } & \multicolumn{2}{|c|}{$\begin{array}{l}\text { Pre-cultured } \\
\text { milk }\end{array}$} & \multicolumn{2}{|c|}{$\begin{array}{c}\text { Pre-cultured milk } \\
+ \text { proteose peptone }\end{array}$} \\
\hline & $\begin{array}{l}\text { Population } \\
\text { ratio a }\end{array}$ & $\begin{array}{l}\mathrm{pH}^{\mathrm{b}} \\
\text { difference }\end{array}$ & $\begin{array}{l}\text { Population } \\
\text { ratio a }\end{array}$ & $\begin{array}{l}\mathrm{pH}^{\mathrm{b}} \\
\text { difference }\end{array}$ \\
\hline \multicolumn{5}{|c|}{ L lactis subsp lactis } \\
\hline CNRZ 141 & 0.50 & +0.11 & 1.38 & -0.02 \\
\hline CNRZ 145 & 0.23 & +0.11 & 1.00 & -0.02 \\
\hline CNRZ 261 & 0.80 & +0.02 & 2.27 & -0.21 \\
\hline CNRZ 377 & 0.37 & +0.12 & 0.96 & -0.01 \\
\hline \multicolumn{5}{|c|}{ L lactis subsp lactis biovar diacetylactis } \\
\hline CNRZ 125 & 0.54 & +0.05 & 1.00 & +0.01 \\
\hline CNRZ 187 & 0.30 & +0.14 & 1.83 & -0.27 \\
\hline CNRZ 257 & 0.50 & +0.21 & 0.98 & -0.03 \\
\hline CNRZ 267 & 0.67 & +0.08 & 1.39 & -0.09 \\
\hline \multicolumn{5}{|c|}{ L lactis subsp cremoris } \\
\hline CNRZ 112 & 0.65 & +0.04 & 1.00 & -0.03 \\
\hline CNRZ 114 & 0.54 & +0.12 & 1.31 & -0.06 \\
\hline CNRZ 379 & 0.12 & +0.08 & 0.95 & 0.00 \\
\hline CNRZ 380 & 0.59 & +0.07 & 1.59 & -0.22 \\
\hline Mean & $\begin{array}{l}0.48 \\
\pm 0.11\end{array}$ & $\begin{array}{l}+0.10 \\
\pm 0.03\end{array}$ & $\begin{array}{l}1.31 \\
\pm 0.24\end{array}$ & $\begin{array}{l}-0.08 \\
\pm 0.05\end{array}$ \\
\hline
\end{tabular}

Cell density and $\mathrm{pH}$ were taken after $4 \mathrm{~h}$ of incubation at $30^{\circ} \mathrm{C}$. ${ }^{\mathrm{a}}$ : Cell density in pre-cultured milk / cell density in control milk. $\mathrm{b}: \mathrm{pH}$ of the pre-cultured milk minus that of the control milk. Milk $\mathrm{pH}$ and cell densities after preculturing were $5.3 \pm 0.3$ and $(1.2 \pm 0.5) \times 10^{9} \mathrm{cfu} / \mathrm{ml}$ respectively.

La densité de population et le $\mathrm{pH}$ du lait étaient mesurés après $4 \mathrm{~h}$ d'incubation à $30^{\circ} \mathrm{C}$. ${ }^{a}$ : densité de population du lait précultivé / densité de population du lait témoin. ${ }^{b}: \mathrm{pH}$ du lait pré-cultivé moins celui du lait témoin. Le pH et la densité de population du lait en fin de pré-culture étaient de $5,3 \pm 0,3$ et $(1,2 \pm 0,5) .10^{9}$ ufc/ml, respectivement. 
Consequently, pre-cultured milks were less acidic than controls, with all samples exhibiting positive $\mathrm{pH}$ differences.

As expected, adding proteose-peptone $(0.1 \%)$ to pre-cultured milks suppressed inhibition of all second cultures, with the population ratios ranging from 0.95 (strain CNRZ 379) to 2.27 (strain CNRZ 261). Consequently, $\mathrm{pH}$ differences were negative or close to zero, ranging from +0.01 (strain CNRZ 125) to -0.27 (strain CNRZ 187). As mean population ratios and mean $\mathrm{pH}$ differences were markedly different from one and zero respectively, addition of proteose-peptone to pre-cultured milk restored growth of some strains and/or stimulated the second cultures of some others, as exemplified by strains CNRZ 261, 187 and 380 .

\section{DISCUSSION}

Pre-culturing milk with a particular proteolytic strain of Lactococcus lactis inhibited subsequent cultures of the same $\mathrm{pr}^{+}$or an isogenic prt variant, with both the type and extent of inhibition dependent upon population levels attained by the preculture.

When $\mathrm{prt}^{+}$strain pre-cultures were stopped before the end of the first exponential growth phase, subsequent growth rates and maximum populations of the prt strain was reduced. In contrast, the secondary culture of the prt $^{+}$strain grew quite well, with only slight inhibition noted from an earlier change in growth rate. Behaviour of both strains is easily explainable. During the first exponential growth phase of the $\mathrm{prt}^{+}$strain used as a pre-culture, NPN in milk was consumed. Consequently growth of the prt strain as a second culture was apparently limited by partial depletion. When all the NPN naturally present in milk was consumed by the preculture, the prt strain was apparently no longer able to grow. However, since the $\mathrm{prt}^{+}$strain is by definition proteolytic, this strain can enter a second growth phase as soon as the remaining milk NPN has been exhausted.

When pre-culturing was continued beyond the level at which a change in exponential growth phases of the $\mathrm{prt}^{+}$strain occurred, the same $\mathrm{prt}^{+}$strain, as a second culture, continued to grow due to its proteolytic activity; whereas the prt strain was completely inhibited, regardless of the level attained by the prt $^{+}$strain in pre-culture. Thus, during the second exponential growth phase of pre-culture, the proteolytic strain apparently grew in milk without accumulating enough assimilable NPN to support subsequent growth of the isogenic prt strain. With no more NPN available, the $\mathrm{prt}^{+}$strain used as second culture had to rely on its own proteolytic activity for growth. This is why the organisms' growth rate was similar to that observed in control milk during the second exponential growth phase.

It is now easy to understand why addition of NPN to pre-cultured milk restored or enhanced the growth of the second cultures. Their growth was no longer limited by the NPN content of milk. The prt strain was able to attain the same population level as that of the parental strain, both being limited only by the low $\mathrm{pH}$ value of milk. Since new growth rates were similar to those for both strains in the first growth phase in control milk, proteose-peptone likely has the same nutritive value as milk NPN.

Using 12 other lactococci strains, preculturing milk with $\mathrm{prt}^{+}$strains inhibited the same strain or a corresponding prt variant in a second culture. Furthermore, addition of NPN stimulated or at least restored growth. Hence it appears that what has been observed with the reference $\mathrm{prt}^{+} / \mathrm{prt}$ pair is a common feature of other $L$ lactis strains when grown in milk. 


\section{REFERENCES}

Bande SP, Anantharamiah SN, Anantakrishnan CP (1970) Libération d'acides aminés dans les cultures sur lait de Lactobacillus casei et Streptococcus lactis. 18th Congr Int Lait 1F, 120

Hassan Al, Deschamps N, Richard J (1989) Précision des mesures de vitesse de croissance des streptocoques lactiques dans le lait basées sur la méthode de dénombrement microbien par formation de colonies. Etude de référence avec Lactococcus lactis. Lait 69, 433-447

Hugenholtz J, Dijkstra M, Velkamp H (1987) Amino-acid limited growth of starter cultures in milk. FEMS Microbiol Ecol 45, 191-198

Huggins AM, Sandine WE (1984) Differentiation of fast and slow milk-coagulating isolates in strains of lactic streptococci. J Dairy Sci 67, 1674-1679

Ibragimova AZ, Novotel'Nov NV, Shmeleva LI (1973) Consumption and accumulation of free amino acids during milk fermentation by lactic acid streptococci. Dairy Sci Abstr 36, 659

Juillard V, Richard J (1989) Etude de l'interaction entre souches protéolytiques de streptocoques lactiques mésophiles et leurs variants non protéolytiques, au cours de leur croissance dans le lait. Lait 69, 291-304

Juillard V, Richard J (1990) Indirect interaction in milk between isogenic strains of Lactococcus lactis. I. Effect of pre-culturing by a non proteolytic variant. Lait 70, 425-438

Kamaly KM, Marth EH (1989) Enzymes activities of lactic streptococci and their role in maturation of cheese: a review. J Dairy Sci 72, 1945-1968

Lawrence RC, Thomas TD, Terzaghi BE (1976) Review of the progress of dairy science: cheese starters. J Dairy Res 43, 141-193

Monod J (1949) The growth of bacterial cultures. Ann Rev Microbiol 3, 371-394

Terzaghi BE, Sandine WE (1975) Improved medium for lactic streptococci and their bacteriophages. Appl Microbiol 29, 807-813 